\title{
A singularidade de Dadi \\ no Teatro de Bonecos: um \\ olhar na brincadeira do \\ João Redondo no RN
}

DoI

http://dx.doi.org/10.11606/ 2179-0892.ra.2018.145523

\author{
- Universidade Federal do Rio Crande do Norte / Natal, RN, Brasil \\ $\boldsymbol{\nabla}$ galnatal@hotmail.com
}

Maria das Graças Cavalcanti Pereira

\section{RESUMO}

O presente artigo tem por objetivo evidenciar a singularidade da "calungueira" Dadi, ressaltando as transgressões realizadas por essa fazedora de bonecos num campo marcado pela genealogia historicamente masculina da tradição no Teatro de Bonecos do Rio Grande do Norte. Com 76 anos, Maria leda da Silva Medeiros - conhecida como Dadi -, constrói, veste, dá vida e movimento aos bonecos. A subversão dessa lógica na criação e no brincar perante bonecos e bonequeiros traduz seu diferencial ao provocar o riso nas pessoas apresentadas no decorrer da pesquisa. Para o arcabouço teórico foi utilizado o aporte teórico-metodológico das Ciências Sociais e da Antropologia, referências dos estudos culturais com abordagens sobre Memória e Tradição de autores como Halbwachs (1990) e Paul Zumthor (1993, 1997, 2005), entre outros, proporcionando ao trabalho uma atualidade relevante ao dialogar com diversos elementos e significados na produção de sentidos da singularidade da Mestra Dadi.

\section{PALAVRAS-ChaVe}

Calungueira, teatro de bonecos, João Redondo, tradição 


\section{INTRODUÇÃO}

Este artigo evidencia a singularidade de uma "calungueira" - fazedora de bonecos-que apresenta o seu diferencial no Teatro de Bonecos Popular do Nordeste. Trata-se de Maria leda da Silva Medeiros, 72 anos, conhecida por Dadi, residente em Carnaúba dos Dantas, município do Rio Grande do Norte-RN. Sua inventividade extrapola os habituais bonecos de luva', encontrados na maioria dos brincantes. Ela constrói marionetes de fios ${ }^{2}$ e de vara ${ }^{3}$, de grande porte, com membros articulados, lembrando os santos de roca ${ }^{4}$, utilizados na abertura de eventos, anunciando que ali vai haver uma apresentação do Teatro de Bonecos.

No Brasil, não há documentação que determine as primeiras manifestações da chegada do Teatro de Bonecos. A hipótese mais recorrente nos autores que tratam dessa temática é a de que teria chegado ao nosso país trazido pelos portugueses, no século XVI, como presépio - uma representação do nascimento de Jesus Cristo. Assim deu origem a duas formas de teatro: a dos pastoris, espetáculos do ciclo natalino encenado por atores, e a de mamulengo, espetáculos encenados, em várias ocasiões, por bonecos de madeira.

No Rio Grande do Norte, essa forma de teatro é denominada de "João Redondo", ou "Calunga", recebendo outras nomenclaturas em outros estados nordestinos ${ }^{6}$. Possui caráter historicamente masculino na tradição potiguar, representada por alguns mestres ${ }^{7}$ já falecidos ou por seus multiplicadores que, aos poucos, foram inseridos nessa brincadeira com bonecos.

Dadi infringe a regra dessa genealogia potiguar e vai sugerindo uma diversidade de transgressões tanto na feitura dos bonecos, em suas apresentações e em sua vida cotidiana, o que me fez elegê-la e constituí-la como objeto de estudo ${ }^{8}$.

O início dessa pesquisa se deu ao meio-dia da véspera do dia de São José, 18 de março de 2002, quando me encontrava no ponto devocional Monte do Galo, construído em 1927. Nessa época eu estava inserida no projeto "Santeiros e Devoções do RN", no Museu Câmara Cascudo da Universidade Federal do Rio Grande do Norte (UFRN). Esse projeto tinha como proposta mapear os pontos devocionais do RN, os tipos de materiais utilizados nas oferendas feitas aos santos de particular devoção, como também saber de onde esses romeiros migravam e o registro fotográfico das peças expostas na sala dos milagres.

O ponto devocional Monte do Galo está localizado num lugar aprazível, a 155 metros de altura, situado no município de Carnaúbas dos Dantas, Região do Seridó potiguar. Ponto conhecido de romaria, possui escadarias intercaladas por rampas, nas quais se pode ouvir os romeiros.

Entrevistei uma pessoa que me deu referências a respeito de pessoas da cidade que fabricavam objetos para pagamento de promessas. Ali morava Dadi,
1 Bonecos de luva são os que possuem só a cabeça e as mãos em madeira ou outro material leve, tendo o corpo em forma cônica, como um camisolão. A mão do titereteiro ou bonequeiro produz movimentos com o dedo indicador enfiado em um furo na cabeça do boneco e os dedos polegar e médio nos braços, por debaixo do camisolão.

2 Bonecos de madeira ou de outro material leve, com fios ligados à cabeça, ao tronco e aos membros, partindo de uma armação de madeira em forma de cruz, que possibilitam aos mestres fazerem qualquer movimento com os bonecos.

3 Boneco de vara tem o corpo esculpido em madeira e possui vareta central que permite sustentação e controle.

4 Por estátua de roca se entende aquelas imagens sacras que se destinam a ser levadas em procissão e que são vestidas com trajes de tecido. Esse gênero de imagens adquiriu considerável importância no culto católico, especialmente durante o período barroco, estendendose até meados do século XIX.

5 [...] os mais antigos contavam que há muito tempo atrás existia um homem muito rico, tenente, capitão, coronéis. ..."esses nomes", que segundo Chico, "naquela época a gente sabia quem era rico". Chico relata que esse homem chamava-se João e que na fazenda tinha uma mulher negra, $D$. Inês, que tinha dois filhos, Baltazare Benedito. O fazendeiro cuidava dos meninos como se fossem seus filhos. Um dia depois da morte do fazendeiro, os meninos resolveram fazer 
uma fazedora de ex-votos $^{9}$. De imediato segui em busca da artesã para fazer o registro. Para minha surpresa, ela me descortinou mais um saber/fazer que era dotada, mostrando-me outro universo no qual ela transitava muito bem: o Teatro de João Redondo.

A partir da evocação dessa brincante, comecei a pesquisar esse tipo de teatro, que até aquele momento me era desconhecido, partindo de uma questão primordial: o que são o Teatro Popular de Bonecos e o de João Redondo?

O João Redondo é um tipo especial de Teatro de Bonecos enraizado de modo profundo na tradição popular do Estado do Rio Grande do Norte. Esse teatro tem como forte característica a fabricação artesanal de bonecos e objetos de cena, geralmente feitos em madeira pelos brincantes/artesãos e a manipulação desses bonecos/personagens com o objetivo de encenar histórias tecidas na tradição, nutridas de improviso e de novidade.

Essa brincadeira ${ }^{10}$ é a responsável pelo entretenimento em sítios e lugarejos, escolas, praças públicas e pequenos circos mambembes, na casa do próprio bonequeiro ou em outro lugar, marcado pelo proponente interessado. Acontece geralmente em áreas abertas, por trás de uma pequena cortina ou tolda, com espaço reservado para o brincante movimentar os bonecos. Essa é uma apresentação magistral de vivacidade, de colorido, de alegria, com ritmo e expressão sem sofisticação, apoiando-se na tradição.

Já a denominação de "Calungas" geralmente designa as bonecas/bruxinhas feitas de pano que têm a forma humana, comumente usadas nas apresentações dos brincantes em algumas regiões, como no $\mathrm{RN}$, quando querem utilizar uma personagem feminina. A mestra"1 Dadi se auto-intitula "Calungueira"12.

Desde o primeiro contato com a brincante Dadi, quando ela já esculpia seus calungas para o teatro de João Redondo, percebi que sua ligação com os bonecos vinha de muito longe, desde a infância. Teve início quando a mãe fazia as calungas em pedra, para entretê-la em casa. A avó materna, Zefinha, levava-a também para assistir às brincadeiras apresentadas, nos arredores de seu povoado, pelo bonequeiro Bastos ${ }^{13}$, que atiçou sua curiosidade de criança de querer descobrir o que estava por trás da empanada14"Naquele tempo não se mostrava o que estava por trás da tolda", afirma Dadi.

A calungueira faz-se presente no contexto da arte de fazer bonecos desde quando era fazedora de ex-votos, quando transgride a regra, escolhendo o caminho do riso, esculpindo seus "calungas", como prefere chamá-los, inserindo-se no Teatro de Bonecos, ao invés de se tornar santeira, profissão almejada pelos que se iniciam na confecção de ex-votos. Essa opção pelo Teatro de Bonecos já (de)marca a singularidade dessa mulher ao inserir-se num universo tradicionalmente de presença masculina.

Ao ampliar minha visão do que seria o Teatro de Bonecos, observei que uma brincadeira e esculpir alguns bonecos e a um deles deram o nome de seu patrão, João, João Redondo. p, 58.

6 Esse teatro toma o nome de "Mamulengo" em Pernambuco; "Babau" na Paraíba; e "Cassimiro Coco" no Ceará e no Piauí.

7 Mestres já falecidos: José, Miguel e Antônio Soares de Assis, conhecidos como os "irmãos Relampo"; Feliciano; Chico Daniel; Francisco Rosa; Joaquim Lino; João Constantino Dantas; Antônio Pedro da Silva; Joaquim Cardoso; Antônio Gordo; Paulo Vicente; José Bernardino, Jeremias Avelino; Sebastião Severino Bastos. Mestres ainda na ativa, recentemente inventariados pelo registro do Instituto do Patrimônio Histórico e Artístico Nacional (IPHAN) para transformar o teatro de bonecos do Nordeste um patrimônio cultural do Brasil: Raul, Heraldo Lins, Ronaldo, Francinaldo, Manoel Dadica, Zé do Fole, Marcelino, Felipe, Tio João, Josivan e Daniel, entre outros.

8 A pesquisa propiciou a elaboração de minha dissertação de mestrado, Dadi e o teatro de bonecos: memória, brinquedo e brincadeira, defendida em 2010, no Programa de PósGraduação em Ciências Sociais da UFRN, sob a orientação do Prof. Luiz Assunção.

9 Pagamento de promessas com partes do corpo afetado pela doença.

10 A atividade de apresentar esse teatro em meio aos artistas que participam, assim como ao público que a ele assiste, é denominada pelo verbo brincar. Regionalmente, esse tipo de representação teatral 
sua configuração não se encaixava no conceito da dramaturgia clássica, a qual examina o trabalho do autor e a estrutura narrativa da obra. Dadi estava enquadrada em uma forma de teatro que tinha uma matriz com temas e personagens fixos, com uma linguagem peculiar, de várias formas de bonecos e estrutura própria, na qual os bonequeiros partem para criar e recriar os enredos, muitas vezes no improviso, podendo inserir novos integrantes e situações, como em um romance coletivo e sem fim.

A partir do conhecimento existente e com o olhar agora mais aguçado, construído e apreendido previamente durante o itinerário acadêmico, comecei a observar as etapas da construção de bonecos por outros mestres brincantes. Isso facilitou a confirmação da singularidade da Mestra Dadi, tanto no seu saber/ fazer quanto no uso de materiais, no ato de esculpir e na exímia pintura em que revela os traços dos calungas, dando-Ihes vida.

Durante a realização da pesquisa totalizei minhas viagens em seis idas e vindas à cidade de Carnaúba dos Dantas. Elas tiveram início em meados de junho de 2008 e duraram até março de 2009. Cada uma dessas viagens teve a duração de uma semana. A necessária atuação em campo implicou na adoção de várias estratégias de registro, tais como registro documental e de campo, entrevistas semiestruturadas, vídeo-documentário e vídeo-fotográficos da brincadeira.

A materialidade desse trabalho resultou na gravação de 98 horas de entrevistas e apresentações, sempre feitas com cautela e sensibilidade, partindo da regra fundamental de que o bem-estar do entrevistado sempre prevalece sobre os interesses da pesquisa.

Nesses registros está contida uma sequência de episódios coerentes, com significado e direção, os quais propiciaram a compreensão de uma rede de sentidos para perceber na arte de ser fazedora de bonecos e do brincar no Teatro de João Redondo a singularidade da calungueira Dadi.

Partindo do exposto, no decorrer deste artigo, para a evidenciação da singularidade dessa brincante, a ideia é conduzir o leitor pela trajetória de vida de Maria leda da Silva Medeiros-a Dadi-, dividindo-a em três cenários, em alusão às apresentações teatrais, e à medida que descerrarmos a cortina, emergirá a arte desta bonequeira, no chão do interior potiguar. Assim como de seus valores estéticos, de suas arte e técnica, proporcionando ao trabalho uma atualidade relevante ao dialogar com os vários elementos que compõem esse mundo mágico, visando contribuir para a ampliação dos estudos dessa forma de teatro no RN, resguardando sua história para as futuras gerações.

Esse reconhecimento e valorização do ponto de vista histórico da tradição e da memória tornam-se necessários para compreendermos a arte do Teatro de Bonecos, além de possibilitar uma ampla reflexão sobre a relevância de Dadi na brincadeira do "João Redondo". é conhecido pelo nome de brincadeira ou brinquedo.

11 Dentro do Teatro de Bonecos do RN Dadi é considerada mestra por seus pares, mas no decorrer da escrita falo sobre a calungueira, que é assim que a mesma se considera, e como brincante do universo da cultura popular.

12 A calunga representa também um orixá em especial, geralmente Oxum ou lansã, padroeiras dos desfiles dos maracatus. As três calungas, representadas em D. Emília, D. Leopoldina e Dom Luís, reforçam a intenção de uso ritual religioso do Xangô/Maracatu, apesar da aparente visualidade europeia. Calungueiro, derivação de Calunga designa, também, o brincante do Rio Grande do Norte.

13 Bastos era mestre do Brinquedo de João Redondo. Conforme afirma Comes (1951), o exequente conduzia sua bagagem - o Brinquedo de João Redondo-a tiracolo, dentro de um baú, percorrendo fazendas e povoados, vilas e cidades do interior sertanejo, para exibir o popular brinquedo em noitadas alegres, animadas pela sua fantasia representativa, contagiando todos os presentes.

14 A representação é feita com o brincante atrás de uma "empanada", que consiste em uma cortina comumente de tecido estampado, sustentada por paus fincados no chão, ou em pedestais improvisados com pedras ou pedaços de madeira. A cortina é chamada também de "torda"(tolda). 
O primeiro cenário, intitulado "Da memória de Dadi, breves impressões de suas narrativas", anuncia as evocações de suas primeiras lembranças, guardadas por anos, repletas de transcrições individuais e familiares, como parte de um processo contínuo e interativo de mudança social, vinculando sua história e seu comportamento com a coletividade, com pequenos e grandes momentos; os passos titubeantes da infância, os desembaraçados da juventude e os lentos da maior idade.

No segundo cenário, denominado "A estética dos calungas de Dadi", serão apresentadas as etapas da confecção dos bonecos da calungueira: escultura, indumentária e adereços, nessa ordem, evidenciando o registro desde a construção, intercalando com fotografias de suas primeiras coleções (1986) e das mais atuais, com detal hamento do processo criativo e de como ela se reconhece nesse universo brincante em que tem vivência.

Depois é a vez da emoção em "Dadi e a brincadeira no Teatro de João Redondo", na composição do terceiro cenário, que se estrutura pela história e alegria vivenciadas pelos diversos personagens, que criam vida pelo seu manipulador, pedindo passagem, gentilmente, aos fios que ajudam a mantê-los vivos. Como pontua Paul Zumthor, "cada performance nova colocando tudo em causa" (2005:39).

Pois, se podemos atribuir uma característica à cultura popular é seu caráter movente, pela impossibilidade de apresentar-se duas vezes da mesma forma, constituindo uma cadeia de comunicação que tem combatido a variadas formas de silenciamento. Assim, desfilam os personagens; a apresentação da brincadeira; a cenografia; a performance e o riso.

O registro dessas memórias mostra o espaço particular da Mestra, com o objetivo de ampliar e atualizar a genealogia desse universo brincante no Teatro de Bonecos do Rio Grande do Norte, incluindo seu nome nesse território mágico e lúdico, dando visibilidade à singularidade desta bonequeira.

\section{DA MEMÓRIA DE DADI, BREVES IMPRESSÕES DE SUAS NARRATIVAS}

Nesse primeiro cenário será mostrada a presença das lembranças de infância, desde as primeiras e decisivas experiências de vida, com reflexões individuais engajadas noutras imagens reportadas ao passado, em especial de sua juventude, até a chegada da maturidade Me apoiei nas reflexões de Halbwachs (1990) e Zumthor (2005), que se dedicaram a pensar a cultura pelo viés da memória, das lembranças e dos esquecimentos.

Esse diálogo com os autores sem dúvida me ajudou a entender aquilo que Dadi estava querendo evocar ou provocar frente às lembranças acumuladas de sua memória, repleta de personagens concretos e imaginários, cheios de tramas, texturas, sabores, aromas, cores, gestos, palavras e silêncios.

Através de suas narrativas, vejo-a entre os diversos personagens idealizados, 
congregando a ideia de revelar a simultaneidade entre os registros de suas memórias, as observações do empreendimento prático da pesquisa, o diálogo com os autores e as imagens.

Fazendo uso do processo narrativo, Dadi começa a se recordar de um passado tão distante, lembrando que seus pais quando se casaram foram morar numa casa pintada de azul, arrodeada de pedras brancas, doada pelo seu avô paterno, localizada no mesmo sítio da família. Suas lembranças partem daí.

Para Zumthor, a casa materna geralmente é a casa em que vivemos os momentos mais importantes da infância (2005: 22). Ela é o centro geodésico do mundo: a cidade cresce a partir dela e causa-nos até espanto quando vamos revê-la com os olhos de adulto. Já para Halbwachs: "Se não nos recordemos de nossa primeira infância é porque nossas impressões não se podem relacionar com esteio nenhum, enquanto não somos ainda um ente especial" (1990: 38). Fato comum nas lembranças de Dadi, quando as crianças eram confiadas à guarda dos mais velhos, elas recebiam o legado dos costumes e das tradições de toda espécie.

Halbwachs nos chama a atenção para o fato de que "a primeira testemunha, à qual podemos sempre apelar, é a nós próprios" (1990: 26). Assim, quando retornamos a uma cidade, aquilo que percebemos vai nos ajudar a reconstruir um quadro, em que muitas partes estavam esquecidas. Tudo se passa como se confrontássemos vários depoimentos.

Como a memória com seus significados particulares inclui a ideia de movimento, Dadi vai descrevendo os aposentos, relatando que percorria com seus irmãos e primos todos os ambientes da casa, brincando de esconde-esconde (não havia portas nos quartos, estes se conectavam uns aos outros) até se cansar.

Na sequência, ela relata momentos difíceis de sua vida, quando o marido adoeceu e ela teve que trabalhar dobrado para manter sua família. Nessa trajetória com altos e baixos, ela se agarrava aos seus sonhos, quando se refugiava na solidão da mata, constante em seus escritos; "o mato era meu mundo imaginário, não havia perigo". Também extravasava para falar sobre seu medo do desconhecido, quando relata o contato com o "mundo fantástico e de assombração": "um dia fui apanhar carvão [...], e escutei vozes na serra", diz um de seus poemas.

Nesse sentido, a memória corporal é povoada de lembranças, afetadas por diferentes graus de distanciamento temporal: a própria extensão do lapso de tempo decorrido pode ser percebida, sentida, na forma de nostalgia. Assim, as "coisas" lembradas são intrinsecamente associadas aos lugares. Não é por acaso que dizemos, sobre uma coisa acontecida, que ela ocorreu no que chamamos "lugares de memória" (Nora, 1993: 25).

Dadi considerava que a válvula de escape para amenizar seus sofrimentos era a poesia, porque através dela podia esvaziar suas tristes lembranças e extrair 
forças para continuar na luta pela vida. Escrever constituía para ela um ato de rebeldia, uma transgressão à ordem preestabelecida, um discurso silenciado.

Sua poesia cheia de encantos e desafios está presente também nos versos que ecoam dedicados à natureza, quando destacam na paisagem os elementos que provocam sensações, despertando emoções que fazem tocar seu corpo de mulher, pondo para fora os diversos fantasmas, como num processo terapêutico, na construção de seu perfil. Nessa reelaboração, vida e poesia se confundem quando ela conta as histórias. Se a vida conjugal não era boa, havia em seu horizonte sempre uma luz que enxergava e lhe dava forças para prosseguir: seus filhos, sua família, que, na sua lucidez de mulher guerreira, não abria mão de conduzir. Tinha suas metas, seus planos, apesar das pedras que encontrava pelo caminho.

Em meio a essas recordações, ela se lembra, de repente, de um baú em que guarda "mais pedaços da sua vida". São fotos e objetos guardados com carinho. Ansiosa em mostrar suas relíquias, tropeça, e todo o conteúdo guardado se espalha pelo chão. À medida que os objetos são recolhidos, vai relembrando mais facetas de sua vida. Nesse processo, faz o resgate de seus "cacos" de muitos tamanhos e de variadas cores, conforme ressalta Edgard Morin: "Mas, nosso mundo da separação, da dispersão, da finitude significa também o mundo da atração, do reencontro, da exaltação. E estamos plenamente imersos neste mundo que é o de nossos sofrimentos, felicidades e amores". (1998: 8)

Assim, observa-se que sempre que Dadi queria ganhar o jogo precisava reinventar-se. Relembro de uma narrativa que aconteceu em sua vida, após receber em sua casa uma equipe de pesquisadores do Departamento de Artes da Universidade Federal de Pernambuco (UFPE): queriam conhecer seus ex-votos. Esse foi o pretexto usado para a proposta de uma encomenda, após aprovação do traço que ela fazia nas cabeças dos ex-votos, para que fizesse uma coleção de bonecos para o teatro de Mamulengos. Lembro que só conseguiu perguntar: "qual o tipo de madeira utilizada?" Vendo como uma resposta afirmativa, eles responderam: "mulungu". Ela parou e disse: "na minha propriedade tem". Dadi encarou essa proposta como mais um desafio. Fez primeiro o Capitão ]oão Redondo, personagem principal da brincadeira. Assim, foi esculpindo os outros personagens que conheceu na infância. Depois dessa encomenda, outras vieram e, entre elas, a de um pastoril, que foi doado pela mestra ao Museu do Mamulengo de Pernambuco.

\section{A ESTÉTICA DOS CALUNGAS DE DADI}

Aquele que confecciona bonecos possui duas leituras em seu trabalho: uma plástica e outra dramática, ambas dependentes uma da outra. A mestra Dadi é completa, aplicam-se as duas linguagens no seu saber-fazer. 


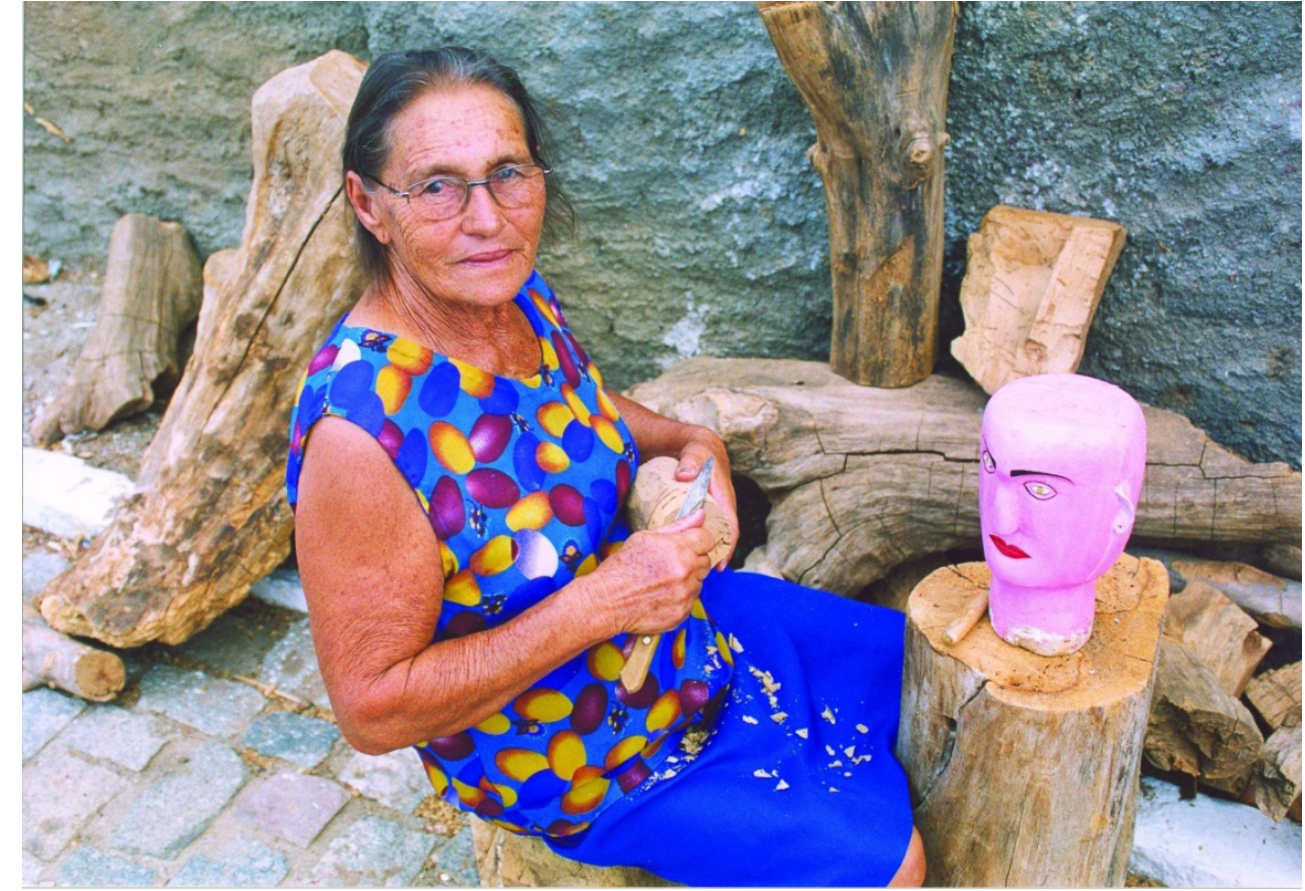

O que Dadi mais esculpe são os bonecos de luva. Em sua confecção, utiliza ferramentas rudimentares, tais como: serrote, facas de vários tamanhos, grosa, formão e furadeira, todas de fácil obtenção em lojas de ferramenta. Com a machadinha, vai contornando a madeira para "desbastá-la"; usa sempre esse termo em sua fala, que quer dizer polir, para aperfeiçoar a peça.

Usa geralmente a faca de ponta fina para esculpir o formato dos olhos, da boca, dos dentes, das sobrancelhas, do nariz, das orelhas, seguindo o desenho das feições. A mão faz em separado, esculpindo-a no formato com os dedos abertos ou com ela fechada sem aparecer os traços dos dedos. No caso de uma mão feminina, diferentemente do que é esculpido pelo universo masculino, inicialmente faz o desenho das unhas, para depois pintá-las.

Às vezes, o boneco todo é feito em um bloco de madeira ou em partes ligadas umas às outras com cola, prego ou massa de modelar para disfarçar. Depois passa cola na peça, espera secar, lixa e segue com a pintura. Nessa fase, o registro demorou um pouco mais, aguardado o tempo de secagem da tinta, responsável pelo tom da pele do boneco, da feitura da maquiagem e colagem do cabelo.

No decorrer das etapas de confecção dos bonecos, Dadi sempre

\section{Figura 1}

Etapa inicial da construção dos bonecos de Dadi. Foto: Fernando Pereira.

\section{Figura 2}

Mão feminina da boneca de grande porte feita por Dadi. Foto: Manoel Bezerra 
surpreende, principalmente com a execução rápida de seu traço preciso, mesmo com a chegada da idade. Quando percebia meu olhar admirado, justificava dizendo: "Já trabalhei muito no pesado, isso que para você é um esforço, para mim é bobagem". Pois esse ofício parece ser árduo, por exigir um esforço muscular considerável dos dedos, do punho, da vista e das costas; o corpo inteiro participa, até a língua, pois tudo aparece, pronunciando-se.

Para a construção dos pares de bonecos de grande porte que constrói por encomenda, Dadi usa a furadeira para encaixar as articulações dos membros inferiores e superiores, como também para fixar os sapatos. Para isso, pede a ajuda de um de seus filhos, João Maria, que é marceneiro. Faz primeiramente o boneco e depois a boneca, por acreditar que esta seja mais difícil, pois tem de contornar os seios e as feições que são mais finas.

No I Encontro de Bonecos e Bonequeiros do Teatro de João Redondo, ocorrido em agosto de 2011, dentro da programação do Agosto da Alegria, na Vila Feliz, em Pium, distrito de Parnamirim/RN, os mestres que estavam dentro da programação tiveram a oportunidade de conhecerem o casal de bonecos de grande porte de Dadi. Alguns os acharam muito interessantes, chegaram até a construir alguns exemplares, mas por considerarem sem muita funcionalidade para a brincadeira, pararam de confeccionar.

$\mathrm{Na}$ etapa voltada para o acabamento do calunga, observa-se a delicadeza e exigência de Dadi: gosta de ver seus bonecos lordes ${ }^{15}$. Percebe-se que os valores estéticos vão sendo construídos no processo de dar forma ao boneco, desde a escolha da madeira até a sua finalização por meio de um acabamento bem refinado, o que fica evidenciado em sua fala:

Quando termino de moldar a cabeça e mãos do boneco, dou um acabamento com lixa, aplico duas camadas de cola branca, para preencher as imperfeições da madeira, aguardo o processo de secagem e, depois de tudo isso, eu aplico tinta lavável, para dar o acabamento final, em que escolho geralmente os tons de rosa, creme, preto e branco para pintar meus calungas.

Dadi também acredita que o bom acabamento da peça vai influenciar diretamente na sua limpeza visual. Explica, ainda, que "esse acabamento se refere a uma pintura bem feita, um bom arremate no tecido das indumentárias, ou uma boa mão de lixa sobre o boneco".

Além desses cuidados, observam-se também as particularidades dispensadas às peças, como aquele acabamento que o público não vê, por exemplo. Uma boa forração na prega da vara, na colagem do camisolão ao pescoço do boneco ou mesmo o requinte de fazer suas roupas íntimas, uma vez que, mesmo aparentemente não tendo muita utilidade, são importantes e influenciam direta-
15 Segundo o dicionário Houaiss da língua portuguesa lorde é um título honorífico inglês. Dadi, porém, o utiliza para dizer que gosta de ver os bonecos muito arrumados. 


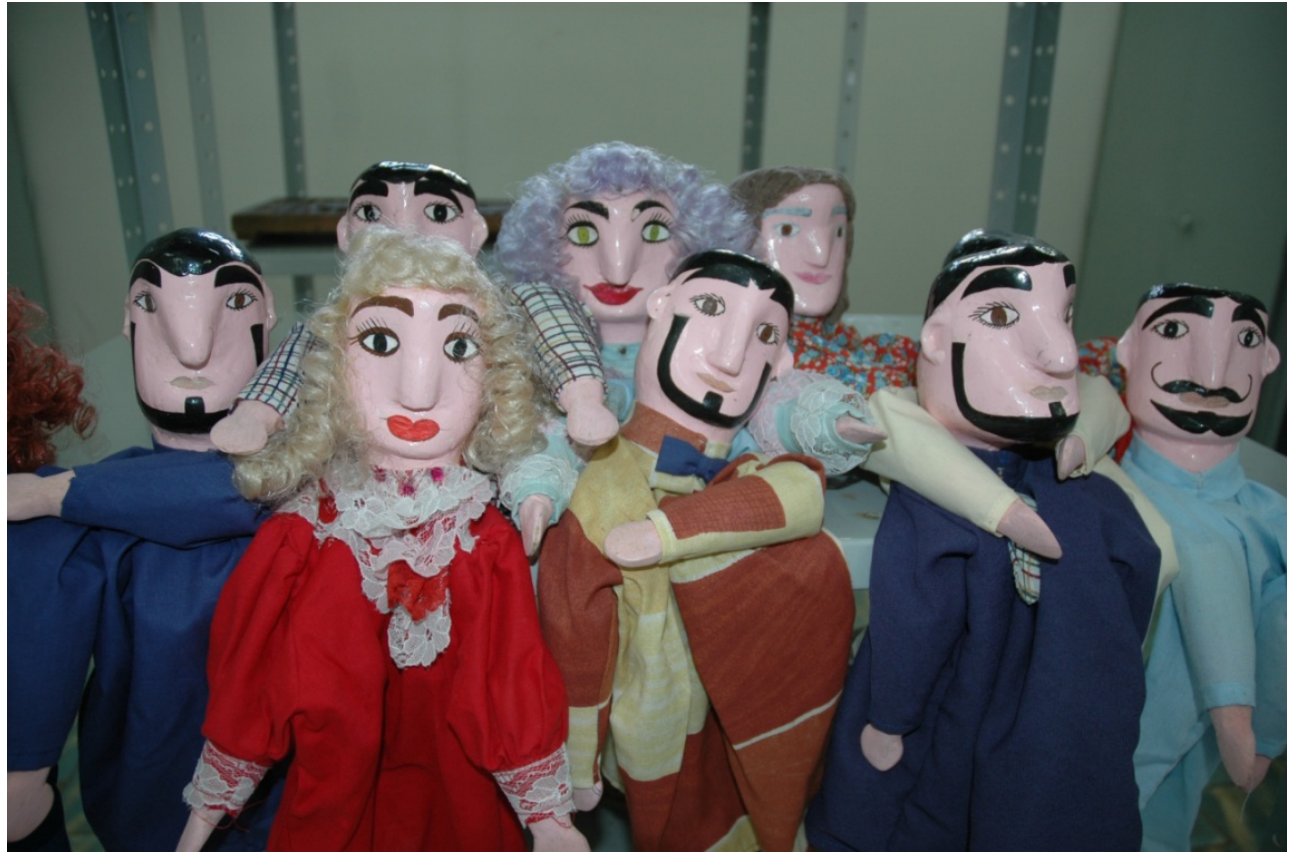

mente no carinho e na atenção que a mestra dá na criação de seus bonecos.

Por gostar de vê-los bem arrumados, Dadi capricha nos acessórios, transgredindo a regra que rege a maioria dos mestres brincantes ao preferir a colagem de cabelo humano ou de crina de cavalos ou mesmo pintados com as cores padrão. Ela, por sua vez, prefere utilizar fios de nylon coloridos (verde, azul, lilás, loiro, ruivo, entre outros tons), imprimindo sua marca singular no efeito visual dos bonecos.

A indumentária dos bonecos de luva é feita em tecido, cortada em formato de cone, como um camisolão, em que a cabeça é adaptada. Na extremidade dos braços são acomodadas as mãos. A escolha mais utilizada pela maioria dos brincantes do RN, para a confecção da indumentária dos bonecos é a chita ${ }^{16}$, por ter esse pano um colorido alegre para fazer a transmissão dramática de múltiplas expressões de cada boneco, como se o seu uso fosse sua própria pele.

Em relação à indumentária, Dadi foge à regra geral da maioria dos brincantes quanto à utilização da chita, por gostar de vê-los lordes; ela escolhe outros tecidos, de preferência aqueles que menos se amassam, para que estejam sempre arrumados.

O registro fotográfico da primeira coleção de Dadi revela uma indumentária com cores básicas, como os tons de azul marinho, verde e amarelo. Para a tez dos da maioria dos bonecos ela faz uma mistura, para ficarem rosados. A exceção na cor só para o personagem Baltazar, que é preto.

No início ela utilizava poucos adereços e os cabelos, olhos e sobrancelhas eram pintados de preto, repetindo o mesmo padrão dos bonecos que viu na sua infância, sem muito colorido. Depois, começou a transferir seu gosto pessoal para os bonecos, sem se preocupar em seguir modelos.

\section{Figura 3}

Coleção de bonecos de Dadi. Foto: Manoel Bezerra.
16 Chita é um tipo de tecido com um número muito reduzido de fios e que é sempre estampado para que a pintura encubra as falhas. 


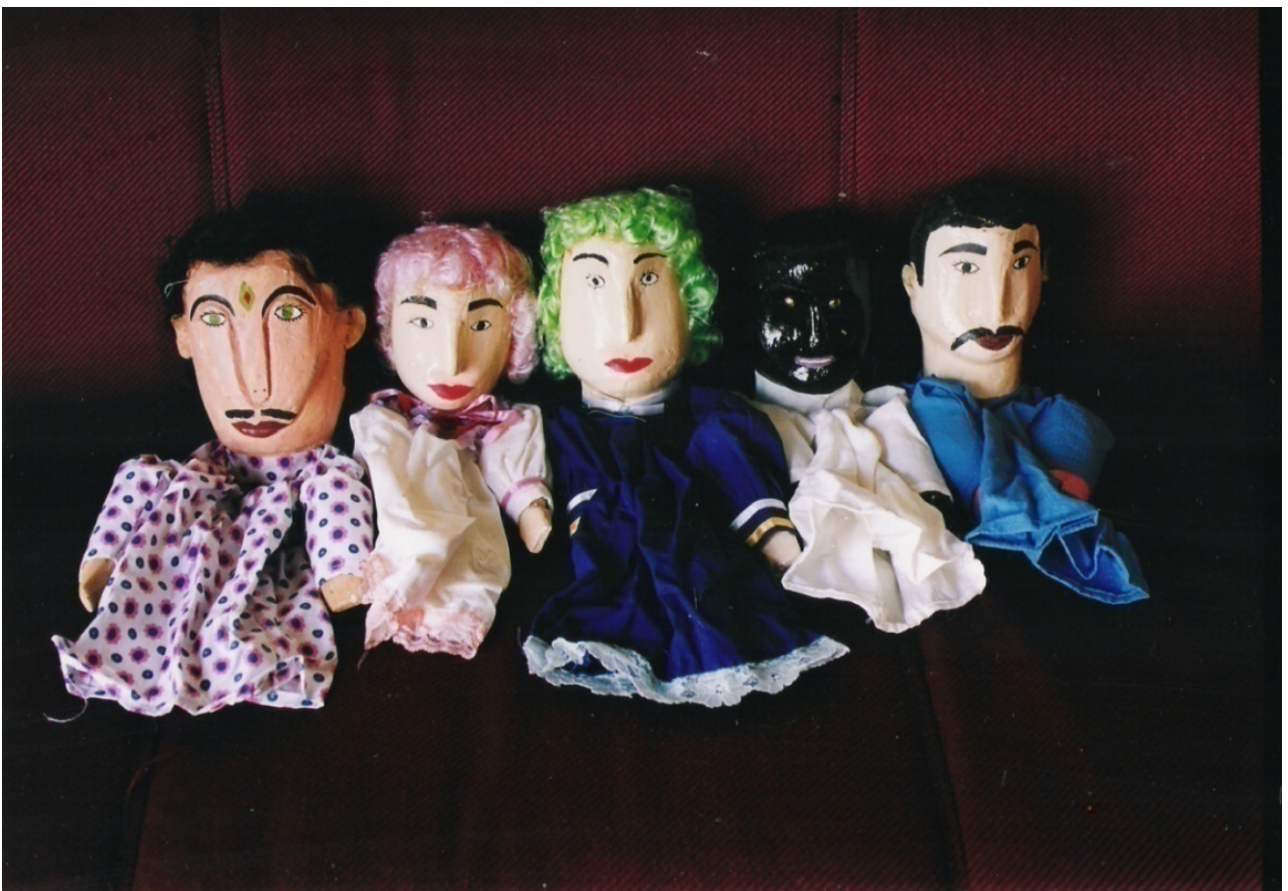

Coleção dos primeiros bonecos feitos por Dadi. Foto: Fernando Pereira

Dadi lembra que repetiu o mesmo padrão dos bonecos que viu na sua infância, sem muito colorido. Depois, começou a transferir seu gosto pessoal para os bonecos, sem se preocupar em seguir modelos.

Usa nos aviamentos muito brilho, principalmente nas roupas femininas. Enfeita a indumentária das personagens femininas com muitos babados, bicos coloridos, cintos brilhantes, broches e laços. Nas figuras masculinas, dependendo da função exercida na brincadeira, veste camisas de mangas compridas, gravata e, por cima, o paletó. Na lapela coloca um cravo vermelho, que causa um grande efeito visual e se harmoniza com o uso do chapéu e o enredo na brincadeira.

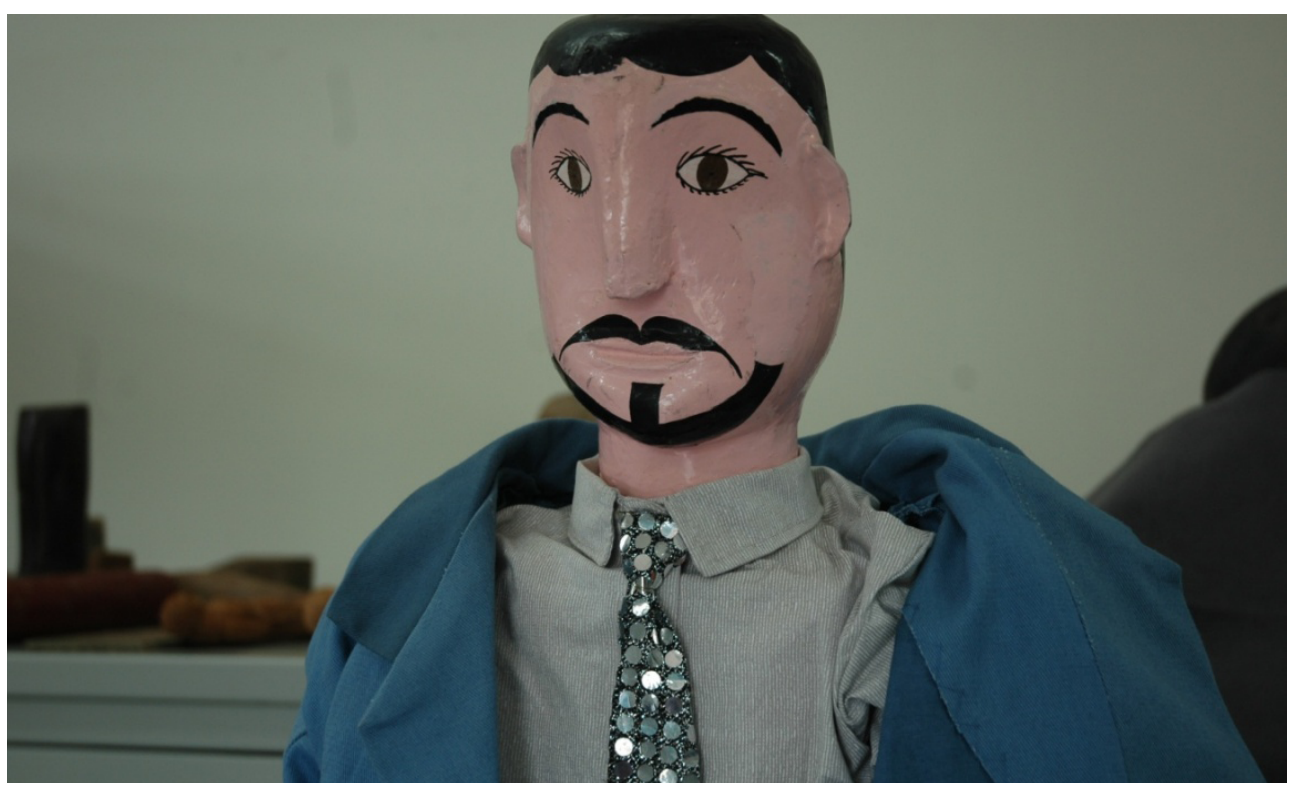
masculina dos bonecos de grande porte de Dadi. Foto: Manoel Bezerra. 


\section{Figura 6}

Indumentária feminina com adereços feitos por Dadi. Foto: Manoel Bezerra.

A respeito das variadas formas de bonecos, Dadi se mostra interessada em aprender outras maneiras de confeccioná-los, sempre se reinventando, trocando experiências com outros mestres, o que gera muita expectativa quando ela diz: "Fiz outra coleção". Sabe-se que vêm surpresas, quer seja nos adereços ou na indumentária ou mesmo na confecção de objetos cênicos para as personagens.

Dadi construiu, no quintal de sua casa, uma oficina para confeccionar seus bonecos, guardar as ferramentas e a madeira. Quando os bonecos ficam prontos guarda sempre dentro de casa, num quarto em que dormem as visitas. Sente-se protegida com eles dentro de casa.

A maioria dos mestres segue a tradição de possuir malas em madeira e outros materiais para acondicionar seus calungas, bonecos, ou "meninos", como alguns

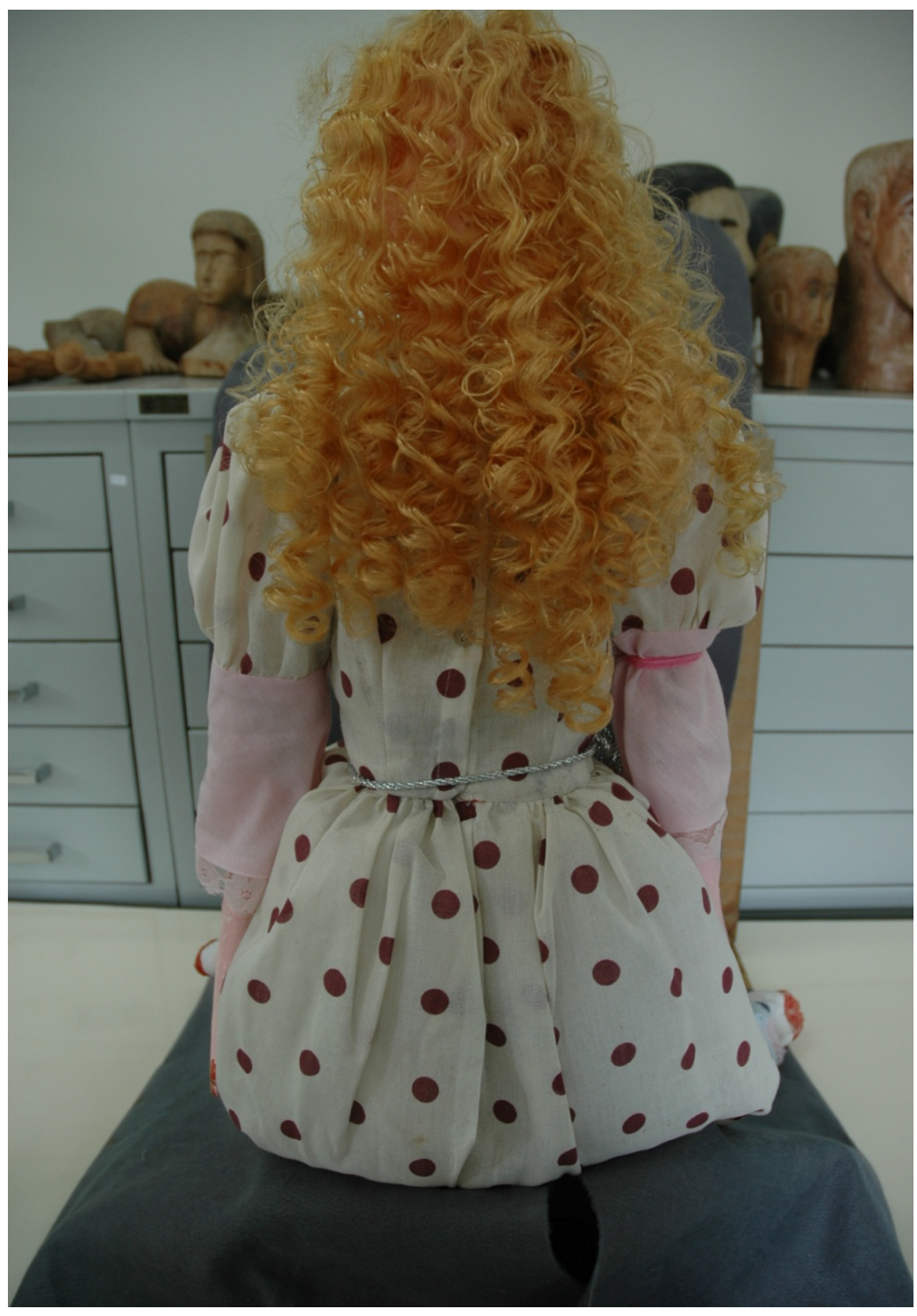


chamam. Quanto maior for o "terno"17, mais espaçosa será a mala. A mestra Dadi tem um baú de madeira grande para guardá-los arrumados, como se fosse fazer uma apresentação, com um total de 30 bonecos de luva, 2 de vara, 2 de fios, três objetos cênicos (cavalo, sanfona, cobra), 2 bonecas de pano, além dos personagens confeccionados por seu neto Werley, como uma banda de rock, que guarda também em sua mala. Para alguns mestres brincantes dessa forma de teatro, o ato de carregar a mala é como segurar um santuário. Para Dadi são objetos sacralizados.

Dadi sabe da importância do papel que assumiu perante a sociedade e tem consciência de que a produção de seus calungas, em suas várias etapas, torna-se um gesto pessoal e único, confirmando sua própria singularidade.

Possuidora de outros traços marcantes, como a confiança no poder das palavras, o abandono da posição de vitima e a recusa ao pessimismo, ela tem a voz, o rosto e o nome impressos na história, como mestra brincante do Teatro de Bonecos no Rio Grande do Norte, como guardiã de uma história, da memória e da tradição desse patrimônio cultural do Brasil.

\section{DADI E A BRINCADEIRA DO TEATRO DE JOÃO REDONDO}

O terceiro cenário é o momento de mostrar a emoção contida no tempo e no espaço da brincadeira no Teatro de Bonecos, o qual se estrutura nas histórias das alegrias e das travessuras vivenciadas pelos diversos personagens que criam vida, graças ao seu manipulador.

Mais do que apresentar ou representar, o termo brincar parece melhor adequado para designar o fazer do ator brincante. Na brincadeira, não se representa, simplesmente se brinca. Brinca-se no sentido de que os brincantes apenas se divertem junto com o público, que também participa da brincadeira, predispondo-se ao jogo do improviso.

Aqui se usa o termo brincar na acepção mesma de brincadeira infantil coletiva, como a maioria das brincadeiras infantis, na qual os brincantes, a partir de um acordo sobre uma estrutura, vivem outra vida - uma vida de faz-de-conta-, improvisando livremente, e, principalmente, com disposição para se divertir e a provocar o riso nas pessoas.

No Rio Grande do Norte, a maioria dos brincantes prefere o uso do boneco de luva na sua brincadeira, por eles estarem sempre ao alcance de seus corpos. Então, os limites de um estão ligados aos do outro, pois não conseguiriam se afastar a uma distância mais do que a do braço do brincante.

Segundo Curci "do ponto de vista físico, são dois corpos que, de alguma maneira, têm a intenção de fusionar-se para plasmar uma identidade cênica, a da personagem" (2007: 124). O boneco é colocado em cena como um objeto privile-
17 Os mestres dizem da quantidade de bonecos ou coleções de bonecos. 
giado, encantador, para revelar coisas que, ditas por um ator humano, soariam vulgares ou mesmo ofensivas, como os arrotos, gases, gracejos e pancadarias.

O João Redondo, assim como outras artes em sua essência, é um teatro cuja função estética cria algo para ser visto e apreciado. Hoje em dia são confeccionados bonecos empregando técnicas tradicionais e com novas tecnologias, como as que são vistas no teatro de animação. A matéria-prima utilizada também foi diversificada e a cada dia se amplia. A borracha, o poliéster, o alumínio e até a sucata são usados atualmente, conquistando, assim, novos espaços e adquirindo novas formas e nova linguagem.

Outro requisito debatido na compreensão dessa brincadeira está no fato que o teatro de bonecos dispõe de uma infinita variedade de signos que o intérprete, o mestre brincante, incorpora como uma ferramenta potencial de seu trabalho criativo. Assim, coloca-se em jogo a capacidade de decifrar e interpretar as condições em que esses signos são codificados e decodificados. E, ainda mais, cada representação difere da outra, devido às circunstâncias variáveis, que incluem não só o tempo e o espaço, como também o estado de espírito da plateia e dos brincantes.

A plateia tem uma importância fundamental na encenação da apresentação e de sua reação depende o êxito da brincadeira. E, por falar na plateia, o jogo só se realiza diante dela, para ela e com ela. Há um respeito pela participação dos espectadores que se identificam com os bonecos nas diversas situações das apresentações. Ela dá legitimidade aos brinquedos, elegendo e reconhecendo seus mestres mais criativos. Se o público não é receptivo, não reage espontaneamente ou não participa, a apresentação tende ao fracasso.

Por meio da dança, da música, da movimentação e da cor, imprescindíveis no andamento da apresentação, excita a imaginação do mestre, estimulando e inspirando-o a penetrar nas regras da performance, citadas por Zumthor:

Regendo simultaneamente o tempo, o lugar, a finalidade da transmissão, a ação do locutor e, em ampla medida, a resposta do público, importam para a comunicação tanto ou ainda mais do que as regras textuais postas na obra, na sequência das frases: destas, elas engendram o contex to real e determinam, finalmente, 0 alcance. Em outros termos, performance implica competência, que é o saber-ser. É um saber que implica e comanda uma presença e uma conduta, uma ordem de valores encarnada em um corpo vivo. (2005: 35)

Em outros termos, para esse mesmo autor, performance implica competência, que é o saber-ser. É um saber que implica e comanda uma presença e uma conduta, uma ordem de valores encarnada em um corpo vivo.

Voz, performance, recepção, há algo de físico no reino do Teatro de Bonecos. Físico, como, por exemplo, o gestual e o teatral, como em épocas medievais ou até 
mesmo em épocas mais antigas e, agora, a relação com o ouvinte. O certo é que estamos diante da matéria verbal concreta, que transparece voz e performance.

Zumthor, quando cita em sua obra o teatro de Marionetes, classificando-o de extensão universal, diz que a voz humana, ligada pela obra de arte à totalidade da ação representada, unifica os seus elementos:

Constitui-se como numa espécie de exorcismo, já que o jogo dos bonecos tem sentido graças a uma voz que não Ihes pertence, que, sem obedecer a limites, misturam-se bonecos, atores, objetos animados, danças, mímica, música, ou permanece o mais simples, tendo apenas um objeto que, animado, manifesta a essência de quem o manipula. (1997: 50)

Ora, a voz, segundo Zumthor ultrapassa a palavra (1997:13). Assim, voz implica que é ouvido. O ouvido daquele que fala e o do ouvinte. As vozes das personagens e a busca para aprimorá-las é uma particularidade do Teatro de João Redondo, quando se torna até uma constante, a criação de diferentes vozes para cada personagem.

Enquanto as vozes das personagens femininas se constituem como um grande desafio para os mestres brincantes, para Dadi a dificuldade é fazer a voz de homem. Esse dado é tão importante que os brincantes mais velhos reclamam que não conseguem mais fazer certas vozes. O uso do microfone é uma das saídas para alguns mestres poderem brincar com mais tranquilidade, frente às dificuldades com a fala de alguns personagens. Isso aconteceu também com Dadi.

Ao discutir a função do intérprete e do ouvinte, Zumthor aponta o primeiro como sendo "o indivíduo de que se percebe, na performance, a voz e o gesto, pelo ouvido e pela vista, e, o segundo, como aquele que possui dois papéis: o de receptor" (1997: 24-25). Para ele, a função do intérprete é, pois, a responsável pela sua força enquanto disseminadora do texto oral. No ato da performance de alguns brincantes, introduzem-se signos atualizadores do universo cultural em que se encontra inserido o transmissor, que vão imprimir-lhe mais funcionalidade e significância narrativa.

Para esse autor, pouco importa o estatuto do comunicado, seja ele preparado ou improvisado (como acontece geralmente no teatro de bonecos), fixado ou não por uma escrita anterior, o que importa é que, naquele instante, o texto foi transmitido por uma voz humana, que o transformou em um monumento incomparável, único.

No lugar onde Dadi reside, as pessoas lembram-se da brincadeira que era apresentada na Região do Seridó pelos mestres Jeremias e Bastos. Faziam apresentações itinerantes nos povoados, o que coincide com as recordações de Dadi, que é contemporânea da maioria dos moradores antigos da cidade. Lembram-se 
ainda que os proprietários de sítios ou mesmo de casas particulares faziam um acordo com o brincante e mandavam chamar os vizinhos para assistirem à brincadeira, fosse com luz de candeeiro ou com lampião a gás. Depois o brincante passava a fita para as pessoas pagarem a apresentação com o que pudessem contribuir.

O mestre nos ofícios dessa arte é detectado por seus pares; todos o reconhecem. Eles admitem, inclusive, a influência de outros mestres e afirmam que aprenderam com estes. Essa mistura de elementos apresenta a composição da memória dos mestres brincantes de cada lugar.

Em geral, eles seguem um ofício familiar, de pai para filho. Falam como um processo quase "natural", como ocorria nas corporações de ofício medievais, nas quais as crianças se misturavam aos adultos no dia-a-dia e socializavam-se em diferentes profissões, sem passar por um aprendizado fora da família. Para os que não têm a sorte da proteção do mestre, começam olhando a brincadeira de fora, observando o comportamento dos mestres, para depois imitá-los. E não usam os sobrenomes formais, mas sim, o apelido de família, como acontece no Teatro de Bonecos, no estado do Rio Grande do Norte. Relampo, Daniel, Lourenço, Basílio e Antônio de Rosa em que marcam mais o brincante do que o parente.

Já para sua legitimação, segundo Alcure, "ela é dada não só pelos mestres de outros brinquedos, mas, principalmente, pelo público do mamulengo, que, graças à familiaridade com o brinquedo, sabe avaliar a capacidade e o conhecimento de um mamulengueiro". E a autora ainda diz, na mesma página, que esse teatro "é geralmente composto de homens ingênuos, de boa-fé, que acreditam no que falam às pessoas que têm leitura e não escondem os segredos de sua arte a quem perguntar e estão sempre dispostos, a qualquer hora, de até se apresentarem, se forem solicitados" (2001: 45).

Para muitos brincantes, o princípio da brincadeira está ligado à sua experiência e ao ato de assistir ou de se apresentar pela primeira vez. Com Dadi, não foi diferente. Quando menina, ficava muito curiosa para ver o que estava por trás da empanada do mestre Bastos e, mesmo com sua avó explicando ser apenas um homem que manipulava aqueles bonecos, ela queria comprovar. Momento em que marca e funda uma longa relação com o ato de brincar o "João Redondo".

Dadi lembra que quando era ainda muito pequena, ouviu de sua mãe ao vê-la brincando o João Redondo: "menina, essa brincadeira é de homem!" Naquele momento ela pensou em desistir de fazer a brincadeira, mas a ideia ficava martelando em sua cabeça. Quando a mãe saía para os roçados, o pensamento Ihe perseguia e voltava a brincar com o irmão, usando um sabugo de milho para substituir os bonecos que via o mestre usar quando se apresentava. Esse interesse pela brincadeira estava enraizado nela desde a infância.

O Teatro de João Redondo geralmente é apresentado por detrás de uma tolda amarrada lateralmente por duas varas fincadas no chão ou presa aos caibros 
do telhado da casa, e, no ângulo de uma sala, se posiciona o mestre brincante com sua mala de bonecos. Alguns mestres utilizam um biombo desmontável em ferro ou madeira, medindo 1,80 x1,80, com forma sanfonada e um viés aderente, tipo velcro, em sua parte posterior, para que possa ser preso ao tecido da empanada e manter a magia do interior da tolda na hora da apresentação.

Dadi possui um modelo desse tipo. Na parte interna, ainda colocou um suporte de madeira - como forma de diferenciar-se dos demais mestres-, preparado para enfileirar os bonecos e objetos cênicos, facilitando assim seu manuseio na hora da apresentação. De frente para a empanada espalha-se o público presente ao evento.

A manipulação dos bonecos de luva é feita com a mão por debaixo do camisolão. O brincante introduz os dedos polegar, indicador e médio nos orifícios existentes sob a cabeça e nas mãos do boneco, fazendo toda a movimentação. A manipulação é realizada, geralmente, de baixo para cima, e o contato do brincante com o objeto se dá de uma forma direta, pois boa parte do corpo do boneco é composta pela mão do brincante, que preenche o camisolão.

No Teatro de Bonecos popular do Nordeste do Brasil há uma forma peculiar de caracterização, que se evidencia no nome da personagem, o qual é definidor do seu caráter e do seu comportamento. Essa forma de teatro no RN possui um elenco variado de personagens, em que aparece, primeiramente, o Capitão João Redondo, representante da camada social superior, dominante. Apresenta-se como o arquétipo do proprietário de terras do Nordeste, que usualmente recebe a patente de "coronel". Ele é o "dono da brincadeira", aquele personagem que inicia e termina a apresentação.

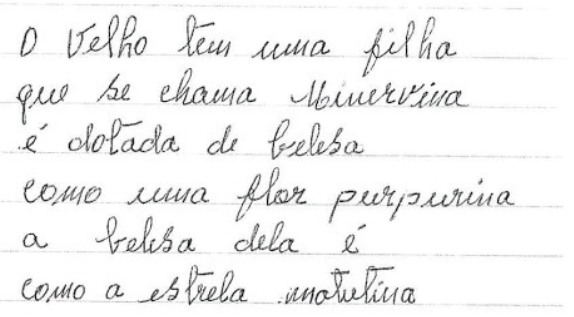

O Capitaĩ tem unidado com a filha Minertina Liur medo dela casar соми geutó que ма̃̈ comfóúa pQis mầ quer que sua filtha traga una trislé sina

\section{Figura 8}

Poema dos Bonecos, manuscrito de Dadi, publicado em 2006 no seu livro de poesias intitulado "Flor de Mucambo". 
O boneco/personagem do Capitão João Redondo encena, na maioria das vezes com o boneco Baltazar ou Benedito, que têm o perfil de um negro mirrado, de voz fina, fraco na aparência, mas, por outro lado, valente, sabido, astuto e cheio de malícia. Ele possui caráter irreverente e vocabulário recheado de palavrões; é justiceiro e questionador das autoridades constituídas; resolve sempre seus conflitos com surras e pauladas. Apresenta-se como representante do inconformismo do povo nordestino.

O mestre brincante procura destacar alguns traços em cada personagem, buscando diferenciá-las uma das outras. As personagens são, normalmente, típicas: o patrão, o soldado, a amante, a bela, a má, o trabalhador, entre outras.

Dadi utiliza em sua brincadeira as personagens consagradas pela historiografia do universo do teatro de bonecos, tais como: o Capitão João Redondo; Benedito ou Baltazar, que se apresenta como valente e é considerado por ela como "o ideal da brincadeira, um boneco muito tradicional, porque é quem comanda tudo; é muito insolente"; Dona Lilia, mãe do Capitão João Redondo; e Minervina de Morais, filha do "Capitão". Essas são as personagens da tradição, que sempre ouvia desde criança, na apresentação da brincadeira por diversos mestres.

Recentemente Dadi construiu uma boneca de madeira que personifica a mulher do Capitão João Redondo, que se apresenta sempre solteiro na brincadeira de vários mestres, apesar de possuir uma filha, mãe e primos (entre outros parentes) nas histórias. Sua esposa, porém, nunca aparece. Ainda sem nome, essa boneca é muito espevitada, de pele rosada, loura, com olhos azuis, sobrancelhas na cor castanha, a boca muito pintada em vermelho. Intenciona fazê-la casar-se com o Capitão João Redondo. Para justificar a criação da personagem diz que ela "estava à procura de um pau que Ihe desse muita sombra" $e$ quando encontra o Capitão João Redondo, intenciona levá-lo ao altar. Esse é o mote do enredo para a sua próxima brincadeira.

Dadi atualiza referências, repertórios e objetos cênicos no cenário de nossa cultura, criando outras personagens, como o Filósofo, por exemplo. Considera-o muito falante, por atender aos cinco sentidos da pessoa, provocando muito riso na plateia quando menciona esses atributos da personagem nas apresentações.

Além das personagens que personificam comportamentos e valores sociais, há os tipos secundários. Aqueles que representam a memória coletiva, os mitos e as crendices populares, como a "alma", a quem o diabo persegue tenazmente. Eles são derivados do ciclo da assombração do bumba-meu-boi, em que a imaginação do escultor, prevendo a função do boneco na brincadeira, comanda a liberdade de intenções da personagem. A alma vestida de branco, com a cabeça muito pequena, a menor de todas, mas com mãos imensas, caídas em cima do camisolão bem comprido, apresenta-se pedindo piedade a todos, causando forte impressão. 
O Médico, a Alma ou Zumbi, o Diabo e o Negro Xangozeiro, apenas pela imitação de gestos, vozes e danças, contagiam o público. O Diabo aparece como uma personagem extremamente rica, que ainda hoje causa medo na plateia, com o objetivo de levar os mortos das histórias para o inferno, sem se importar se são bons ou maus.

Já a presença da Alma traz à cena a própria morte, que carrega as marcas das personagens alegóricas medievais. O Padre é um boneco bastante representativo que, à maneira dos frades missionários, apresenta-se aconselhando todos a evitarem o pecado, lembrando que o "dia do julgamento" está bem próximo. Dadi não gosta de utilizar as personagens da Alma nem do Diabo, pois fica com medo de mexer com coisas do mundo invisível, apesar de pensar que elas estão entre nós.

O número de bonecos/personagens que se apresentam na brincadeira varia por brincante. Muitos podem andar com a mala cheia de bonecos, mas não utilizam todos em uma só apresentação. Quando uma brincadeira é realizada com uma temática definida, a quantidade de bonecos fica programada. Quando brincam sem tempo marcado podem improvisar com mais liberdade e fazem muita briga de facão no baile do capitão, com a utilização de vários personagens.

O texto apresentado pela maioria dos mestres, geralmente, é no formato de diálogos entre dois ou mais bonecos ou de monólogos com muitas ações, conhecidas pelo nome de "passagens"18.

Nessa forma de teatro não cabem às personagens falas extensas, uma vez que isso pode comprometer o ritmo do texto, nem tampouco aprofundamentos psicológicos. Essas personagens são arquetípicas, sintéticas, próximas, sem deixar de serem precisas, sobretudo para as crianças. O que vale é o jogo, as possibilidades de explorar o singular. A ação da personagem é que deve dar sentido ao texto pronunciado pelo manipulador/mestre brincante, por intermédio do boneco.

A dinâmica geralmente ocorre com a sucessão de quadros autônomos que seguem um esquema de pequenas cenas entrecortadas por músicas, com entradas e saídas de bonecos/personagens, acompanhadas de intrigas, que são desenvolvidas, na maioria das vezes, lançando mão do improviso.

Na percepção da calungueira Dadi, os diálogos curtos e o entrar e sair de bonecos, sem demorar muito, funcionam muito bem. Ela acredita que nem sempre as histórias mais longas são as melhores, já que estas geralmente "esfriam" a apresentação. E, comparando seu saber-fazer com o dos brincantes que iniciaram a brincadeira mais recentemente, que tendem a mostrar transformações mais rápidas, vejo que sua performance é muito criativa e animada e que sempre insere novidades nas apresentações.

Para Dadi o palco não é lugar onde apenas se apresenta uma história, mas onde também se vive uma. Assim, observa-se que é dos temas considerados mais
18 Passagens são enredos curtos, com entradas e saídas de personagens, que servem para os mestres brincantes improvisarem. 
fáceis que os brincantes tiram os melhores efeitos no teatro de bonecos. Não há o culto ao autor ou ao manipulador, mas às personagens transfiguradas em bonecos. O mestre brincante se torna um instrumento para que eles brilhem em cena, e não o contrário: "Ele identifica seu boneco com o personagem que é preciso encarnar, e o boneco torna-se verdadeiramente um ser", afirma Borba Filho (1987: 28).

Quanto aos bons improvisos, eles acontecem quando há a habilidade do brincante em complementar as formas estabelecidas, ou seja, dando à cena atualidade, espontaneidade, como se houvesse, a cada apresentação, algo novo, mesmo com roteiros pré-fixados para cada personagem.

Esses improvisos podem ocorrer em um mesmo repertório. Como nos ensina Zumthor, "o texto vibra; o leitor o estabiliza, integrando-o àquilo que é ele próprio. Então é ele que vibra, de corpo e alma” (2005: 63).

Dadi deixa em evidência os espaços no texto, para poder colocar nome de pessoas da plateia, ou, ainda, entrar com o improviso para cobrir os lapsos, a lembrança ou o esquecimento do que a personagem ia falar, ou da piada que se queria contar, ou do que se queria fazer no momento.

Apresenta histórias de trancoso, diálogos amorosos e fuxicos, reproduzindo também a maneira de falar das pessoas em nossos dias. Para isso diz que gosta de estar atualizada em relação aos fatos, às notícias e aos principais acontecimentos do momento. Reconstrói ainda o texto masculino desabusado, incluindo mais humor a cada apresentação.

Algumas histórias até se repetem nas suas apresentações, como acontece com a maioria dos mestres brincantes, tais como: versos e rimas, piadas, loas. Essa forma de teatro também apresenta críticas através do humor, seja a respeito das relações existentes no período da escravatura - que, aliás, continuam até hoje-, como também sobre preconceito, distribuição de renda, racismo e injustiças sociais, dentre outras questões presentes na sociedade contemporânea.

Mesmo havendo algumas transformações no decorrer do tempo, as apresentações bonequeiras seguem esse modelo da linha tradicional, fator que faz com que sejam vistas como aquelas que apresentam sempre "a mesma coisa". Essa tendência escolhe por fazer um teatro apoiado na palavra, com cenas fracionadas.

Antes de começar a brincadeira, Dadi pendura seus bonecos nos suportes dentro da tolda, de acordo com sua ordem na apresentação. Se por acaso precisar levar seu equipamento de som, liga-o antes para ver se está funcionando, utilizando para teste o CD gravado com músicas de trabalho, de sua preferência. A mestra escolhe músicas de forró nessas ocasiões, porque acredita serem as mais animadas e que dão ritmo e alegria à cena, ou seja, que não "esfriam" a apresentação. A música serve, também, para ser colocada entre uma parte e outra, para a dança ou mesmo para preencher um espaço de cena, quando há troca de bonecos. 


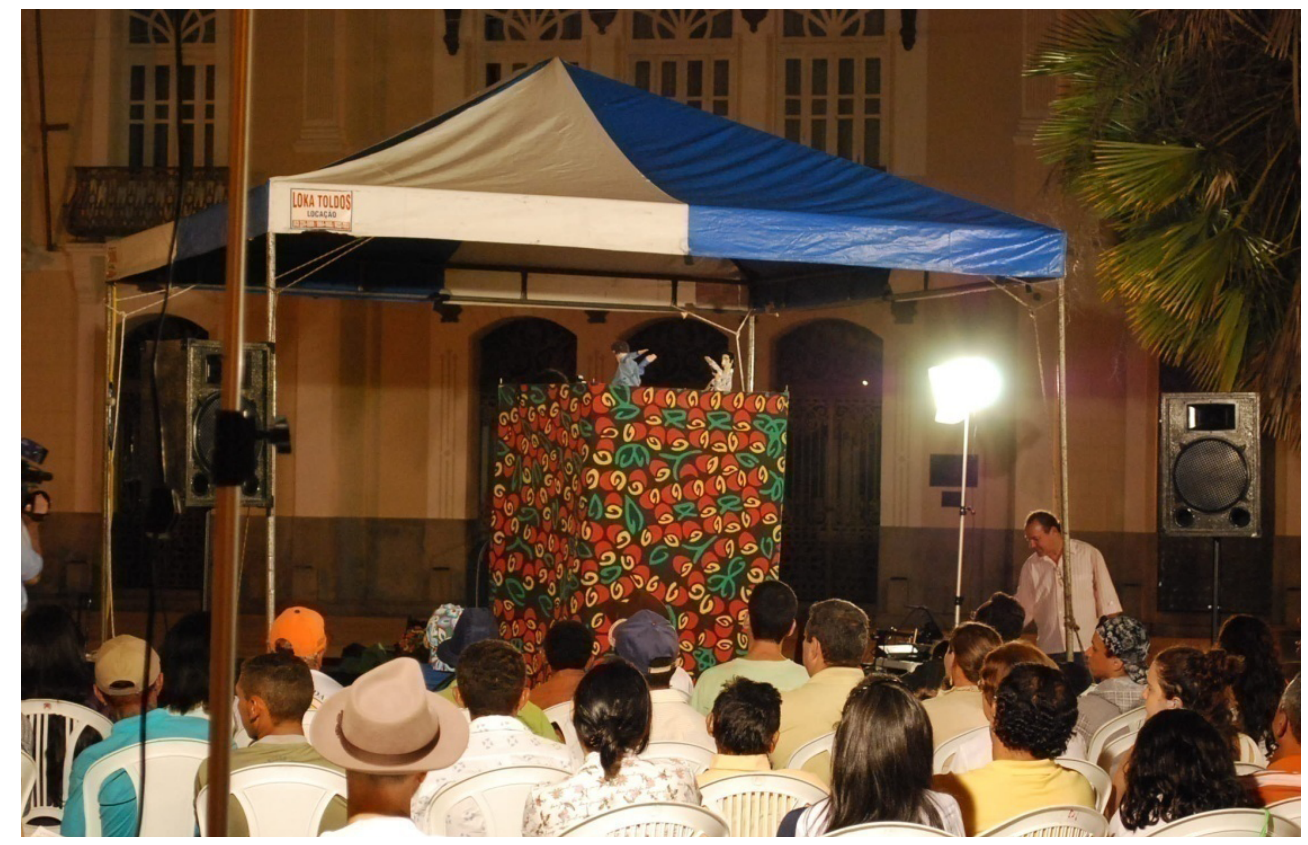

Figura 8

Apresentação pública de Dadi Foto: Alessandro Amaral

Quando inicia sua performance, ela pede logo para suspender a música e o espetáculo começa. Os bonecos são movimentados sobre a empanada, tendo o cuidado de esconder os seus braços por trás da tolda. Há um entra e sai de bonecos, em várias fases, com pequenos intervalos. Sua voz está sempre sintonizada com as características das personagens, sejam elas plásticas ou emocionais. $\mathrm{Na}$ abertura da brincadeira, o boneco vai logo se apresentando, falando seu nome, dirigindo-se à plateia, criando cumplicidade com o público. Quando o boneco não faz sua apresentação é porque ele foi anunciado por outro que o precedeu.

Dadi enfatiza ainda que, depois de tanto "penar" com uma pessoa segurando o microfone para falar, conseguiu comprar um modelo com um suporte de pescoço. Pensa que agora, com o uso dessa tecnologia, que facilitou a saída de várias vozes, sua performance ficou melhor. Antes, sua garganta ficava doendo de tanto falar alto.

Segundo Pavis, "o texto não é somente um objeto de um tratamento pelo corpo do ator, mas também pelos meios da eletrônica sonora" (1999: 207). Nesse processo procura sempre fazer uma voz que tenha a ver com a máscara do boneco da personagem, reforçando sua personalidade, procurando diferenciá-la das outras, ecoando uma vocalidade dramática.

O riso, como é característica marcante do Teatro de João Redondo, parece ser o motor dessa atividade estética, fatura de mundos risíveis, metamorfoseados em desdobramentos poéticos em favor do humor. As histórias são pensadas buscando esse retorno. Desse modo observa-se como o uso da linguagem torna-se componente vital na fala das personagens desse teatro, permitindo relacionar contrastes que partem da criatividade do mestre brincante.

Provoca ainda a aproximação do oposto, e a ironia destrói a pesada oração 
enfática do discurso, conforme defende Bakhtin:

Pela paródia e pelo riso, invertem-se posições previamente fixadas, rompem-se fronteiras e contamina-se o inimigo, incorporando-o e, ao mesmo tempo, deixando-se por ele incorporar, numa promiscuidade geradora que embaça as diferenças e as configurações definidoras, desnudando o outro de sua couraça impermeável. (1992: 78)

O povo ri também das bordoadas, porque não são na sua pele; do valente desmoralizado; das mulheres salientes; das situações e das palavras. O principal do riso está na apresentação das personagens, que quase sempre apresentam valores e comportamentos diferentes das pessoas da plateia, e, quando não, mostram-se com muita coragem, como no caso de Benedito, dotado da habilidade de enganar os outros.

Assim, quando há uma boa estrutura no texto, como espaços para o improviso, saídas e entradas de bonecos organizadas pelo mestre, há um melhor desenvolvimento. Os mestres que não apresentam essa estrutura, muitas vezes ficam perdidos e repetitivos, sem saber o que fazer em cena, com pedidos constantes de música, parecendo um grande baile de bonecos.

Após a atividade, alguns mestres arrumam a mala com os bonecos, desarmam a empanada e retornam para suas casas. A mestra Dadi gosta de fazer a abertura na frente dos espectadores, para desmistificar do imaginário das pessoas, principalmente das crianças, a não existência de muitos manipuladores em ação, mostrando que existe apenas uma brincante encenando várias personagens, fazendo diferentes vozes, além de usar objetos cênicos.

Para Dadi, uma das melhores coisas de ser calungueira é poder apropriar-se de todos os aspectos da profissão: conceber a ideia, criar os bonecos, manipulá- los por trás da tolda e comandar toda a organização que "rodeia" essa atividade, tudo para que não saia nada errado na sua apresentação. Ela considera que, para ser um apresentador do teatro de João Redondo, não só basta manipular bem os bonecos, possuir uma boa voz e trabalhá-la com segurança, moldando as personagens nas várias situações do enredo. É preciso ser dotado de uma privilegiada memória e de uma capacidade de improviso e criatividade, para que não seja quebrado o ritmo do espetáculo.

Além de reconhecer-se como calungueira, Dadi quer sempre formar multiplicadores de sua arte. Para isso, ministra oficina sempre que a convidam. Sente-se realizada pelo reconhecimento de seu trabalho e não esconde segredos na sua forma de esculpir, pois tem prazer em ensinar o que sabe e, quando vê que uma técnica será boa para outra pessoa, a transfere com maior prazer.

Como expressão artística, o Teatro de Bonecos Popular do Nordeste passou a 
ser considerado, em março de 2015, Patrimônio Cultural do Brasil, sendo inscrito no Livro de Formas de Expressão do Patrimônio Cultural Brasileiro como uma forma de expressão genuína da cultura brasileira em que brincantes encenam histórias da tradição, aprendidas e em construção, no meio social em que vivem.

O Brasil é o único país das Américas que apresenta um patrimônio com feitio de tradição teatral, encenada com bonecos e realizada por artistas populares. Embora o mestre seja o protagonista desta forma de expressão, a performance nunca é solitária: por detrás de suas empanadas, os bonecos ganham alma e personalidade em suas mãos e também se tornam protagonistas da cena, demonstrando a intrínseca relação entre bonequeiro e boneco e o modo como a "brincadeira" é, na verdade, uma devoção.

Esta também tem sido a grande devoção de Maria leda de Medeiros, a Dadi, que não se cansa de dizer: "Aprendo todo dia e ensino a quem está interessado. Tenho prazer em brincar, pois me sinto viva em valorizar a cultura popular. Eu dou vida aos bonecos e eles dão vida a mim".

\section{CONSIDERAÇõ̃ES FINAIS}

Procurando ampliar o entendimento dessa brincadeira tão peculiar do RN, defrontei-me não só com a passagem da pesquisa teórica para o domínio do campo, mas com o drama do teatro de João Redondo, baseado no visual interativo, performático, estético e improvisado, na tentativa de contribuir para disponibilizar dados sobre o assunto, refletindo e procurando elucidar aspectos próprios desse fazer, expondo seus processos de construção em diálogo com a contemporaneidade por meio da singularidade da Mestra Dadi.

É esse repertório que mantém e atualiza, por meio do polo da oralidade, a história, a memória e a transmissão do conhecimento às futuras gerações, como aconteceu na pesquisa para o Inventário e foi avaliado pela comissão do Departamento do Patrimônio Imaterial do Instituto do Patrimônio Histórico e Artístico Nacional (IPHAN), com a instrução técnica do Processo de Registro do Teatro de Bonecos Popular do Nordeste, Mamulengo, Babau, João Redondo e Cassimiro Coco, envolvendo tanto a circulação e comercialização dessa brincadeira, quanto os riscos a que a transmissão e a continuação da sua prática estão sujeitas.

Nesse contexto, dei visibilidade a essa calungueira, conduzindo o leitor para dentro do mundo do teatro de bonecos. Tendo Dadi como tema central e puxando por meio dela outros fios, na condução de três cenários distintos, revelando a simultaneidade entre os registros da memória da mestra, o diálogo com os atores e as imagens, para contar a história do boneco e da brincadeira, que é fruto de uma tradição milenar. Por meio desses bonecos, os artistas populares retomam mitos e arquétipos do passado, entre ancestralidade e modernidade. 
Assim, ao serem acionados os recursos da memória, junção das lembranças, relatos, narrativas e os fragmentos que foram ganhando corpo e a forma de textos, a singularidade da mestra Dadi foi evidenciada no Teatro de Bonecos do RN, revitalizando e atualizando sua genealogia, salientando seu dom de provocar o riso nas pessoas, além de promover o interesse de pesquisadores sobre o universo desses fazedores de cultura.

Contudo, nem todas as dúvidas puderam ser dissipadas, o que parece ser natural em qualquer pesquisa, pois não há um começo ou um fim absoluto para um texto, seja ele qual for. Sempre haverá algo mais a se dizer e sempre existirão ecos de que esse algo já foi dito, de alguma forma em algum lugar.

Maria das Graças Cavalcanti Pereira possui graduação em Letras pela Universidade Potiguar (1998) e História pela Universidade Federal do Rio Grande do Norte (2004). É mestra (2010) e doutoranda em Ciências Sociais pelo PPGCS-UFRN.

\section{REFERÊNCIAS BIBLIOGRÁFICAS}

ALCURE, Adriana Schneider

2001 Mamulengos dos mestres Zé Lopes e Zé de Vina: etnografia e estudo de personagens. Rio de Janeiro, dissertação de mestrado, UNIRIO.

BAKHTIN, Mikhail

1992 Estética da criação verbal. São Paulo, Martins Fontes.

BORBA FILHO, Hermilo

1987 Fisionomia e espírito do mamulengo. Rio de Janeiro, INACEM.

CURCl, Rafael

2007 Dialéctica del titiritero em Escena: una propuesta metodológica para la actuación con títeres. Buenos Aires, Colihue.

HALBWACHS, Maurice

1990 A memória coletiva. São Paulo, Vértice/Editora Revista dos Tribunais.

MORIN, Edgar

1998 Amor, poesia, sabedoria. Rio de Janeiro, Bertrand Brasil. 
ARTICo| Maria das Graças Cavalcanti Pereira | A singularidade de Dadi

NORA, Pierre

1993 Entre memória e História: a problemática dos lugares. São Paulo, PUC.

PAVIS, Patrice

1999 A análise dos espetáculos. São Paulo, Perspectiva.

ZUMTHOR, Paul

1993 A letra e a voz: a "literatura" medieval. São Paulo, Companhia das Letras.

2000 Essai de poétique médiévale. Paris, Éditions du Seuil.

1997 Tradição e esquecimento. São Paulo, Hucitec. 


\section{ABSTRACT}

This article aims to point out the singularity of the "calungueira" Dadi and highlight the transgressions carried out by this dollmaker in a field marked by the historically masculine genealogy of the Doll Theater tradition in Rio Grande do Norte. At age 76, Maria leda da Silva Medeiros - known as Dadi-, builds, dresses, gives life and movement to the dolls. The subversion of this logic in the creation of and playing with dolls and dollmakers translates her uniqueness into provoking laughter in the people presented during the course of the research. For the theoretical framework we used the theoretical and methodological contributions of Social Sciences and Anthropology, references from cultural studies with approaches on Memory and Tradition, of authors such as Hal bwachs (1990) and Paul Zumthor $(1993,1997,2005)$, among others, providing this work with relevance when dialoguing with several elements and meanings in the production of meanings of the singularity of Master Dadi.

Recebido em 4 de outubro de 2016. Aceito em 14 de dezembro de 2017.

\section{KEYWORDS}

Calungueira, Theater of Dolls, João Redondo, Tradition 